\title{
Work Environment and Competency to Performance among the SMEs of Keripik Tempe Malang
}

\author{
Ratih Indriyani $^{1}$, Widjojo Suprapto ${ }^{2}$, Monica Dewi ${ }^{3}$ \\ \{ranytaa@petra.ac.id ${ }^{1}$, joe.suprapto@petra.ac.id ${ }^{2}$, monicadewisusanto@gmail.com ${ }^{3}$ \} \\ Petra Christian University, Siwalankerto $121-131^{123}$
}

\begin{abstract}
This study aims to determine the effect of the work environment on employee competency, employee competency on individual performance and the influence of the work environment on individual performance in SME Keripik Tempe Sanan Malang. Questionnaires were used for data collection. The sample was 100 employees work in Keripik Tempe Sanan Malang. The sampling technique is purposive sampling. The analytical method used is Partial Least Square (PLS). The results showed that the work environment had a significant effect on the competency of employee, employee competencies had significant effect on individual performance, work environment had a significant effect on individual performance.
\end{abstract}

Keywords: work environment, employee competency, individual performance

\section{Introduction}

Creative industries have an important role in Indonesia's economic growth [1]. The creative economy sector has exhibited a significant development of $10.14 \%$ annually for the national economy from 2010-2015. Creative industry is an industry that is supported by individual creativity, skills and talents. This industry develops through the creation and utilization of individual creative and creative power [2]. Malang is known as an education city and tourist destination. Malang is now beginning to become one of Indonesia's creative cities. Various creative industrial activities have been developed in the city of Malang, such as creative industry related to culinary/food processing sub-sector [3]. One of the well-known food processing industries in Malang is the tempeh chips processing industry, one of which is produced in the kampong of Sanan. Tempeh chips or keripik tempe are increasingly known as typical souvenirs of Malang and are sought after by tourists [4]. Tempeh chip products have penetrated foreign markets by traditional sales system and by online selling. To support food production in the food processing sector, the employee work intensity and competencies are required. Competence shows individual characteristics related to effective performance in certain work situations. Competence is an important aspect that can support employees in organizations to have good performance, especially as individuals in the organization [5].

The limitation in employee competency, equipments, and various supporting facilities are obstacles for SMEs in general. The activity of tempeh chip production for SMEs in Sanan is done in a home industry that involves the closest people around the house, such as family members and neighbors in one area [6]. Tempeh chip products have been developed into various flavors. The owners of this tempeh chip home industry are self-taught and the business has been carried out for generations [3]. This small industry involves many craftsmen and generates large revenue. The market demand for these products is quite large, so the quality of the tempeh chips must be maintained. One of the constraints for the work environment is the 
limited facilities to work quickly and neatly. The success of business activities, especially SMEs, cannot be separated from the comfortable work conditions and helpful work environment. According to Haslberger and Thomas [7], the work environment can lead to situations where employees will have a high sense of connection and will improve general behavior, abilities, competencies and self-potential to continue working with the organization as a form of job satisfaction compared to working at other places, organizations, or companies. A positive work environment increases the spirit to work, but a negative work environment can reduce work spirit [8].

Individual performance is a result of individual achievements as employees in certain criteria according to a work objective and work processes in a continuous way both individually and collectively [9]. Meanwhile, an employee individual performance is an efficient output and is often associated with productivity that is aimed at optimal results. The result of work performance is shown by comparing work results with work standards that have been set. The problem of SMEs in general is related to productivity, especially in the quality of goods and services produced. The need of employee competency, equipment and various supporting facilities are generally an obstacle for SMEs.

Some previous researches have discussed the effect of employee competence on performance at work. Amiroso and Mulyanto [9] explained that knowledge and skills affect employees' ability to complete their tasks. However, findings from a research by Yossa and Zunaidah [10] explains that employee competence does not have a significant impact on their performance. This is interesting to examine as small and medium enterprises rely their business activities on their employee supports.

A research by Le and Pham [11] examines the effect of work environment on competence in a teaching environment in Vietnamese schools. The finding of this study supports the influence of work environemt in increasing teachers' competency. Several studies were conducted on an empirical study of work environment on performance. However, there is no certain research that discuesses employee competency as an intervening variable between work environment and performance, especially in SMEs.

The aim of this study is to examine the effect of work environment on employee performance. This study also examines the influence of work environment on employee competency and the influence of employee competency on performance. The study is carried out among the employees who work at the tempeh chips home industry center at Sanan, Malang.

\section{Literature Review}

\subsection{Work environment}

The work environment is a part of the work safety of employees related to field conditions, which are the most important part in the process of creating a work environment [10]. In their research, Samani et al [14] explained that organizational success can be described in the field of work environment conditions, that can have impacts on work results. Yusuf and Metiboba [15] stated that the work environment is not only physical, but also all members of the organization in it. The work environment consists of 3 components; they are technical environment, human environment, and organizational environment. Work environment is an aspect that is considered a priority in regulating various factors related to the implementation of work activities in an organization [16]. 


\subsection{Employee competency}

Employee competency refers to the employee's skills and is seen through employee behavior. Employee behavior as a reflection of competence showing what skills employees have [17]. Oswald [18] explains that competence refers to actions in using the abilities, knowledge and expertise owned according to established standards. The suitability of the individual to apply these standards to the field of science that is mastered shows good competency. Human resource competence reflects the ability of human resource to carry out the work which is based on the skills, knowledge and attitude of the employee.

\subsection{Individual Performance}

Individual performance shows that the workforce or individual employees are able to work responsively, fairly and efficiently to achieve the best performance results, in which performance is considered to be some combinations equipped with four elements, namely availability, productivity, competence and responsiveness especially in solving various production problems [18]. According to Jayaweera [13], performance is a behavior or activity carried out to achieve organizational goals and objectives to achieve business success, especially in individuals in completing work tasks. Performance, in particular for individuals, is obtained by individuals's achievement in a certain period compared to work standards in which each organization is required to conduct an evaluation or evaluation to measure the achieved productivity [9]. Performance has the meaning as a work of quality and quantity that has been achieved by an employee in carrying out the tasks in accordance with the given responsibilities [16].

\subsection{Hypothesis development}

Work environment and employee competency. Antwi [20] explains that employees who are competent in their organization have the necessary skills, competencies and ability to express their ideas. They will excel and perform optimally if they are in a favorable environment. According to Yani and Indrawati [20], the work environment can affect employee competencies. A supportive work environment will facilitate individuals in completing the work given. Individuals with a supportive work environment also increase the self-confidence so that they are encouraged to work optimally. The condition of the work environment, both physical and non-physical, is considered to be able to create a more pleasant work situation and to support employees while working. The physical environment can include the availability of tools to a conducive workspace. Nonphysical environment will encourage reciprocal communication so that there are messages, information, knowledge, new thought in the working environment

\section{H1: Work environment has a significant effect on employee competencies}

Employee competency and individual performance. Competence is needed to support specific roles related to job performance [21]. Amiroso and Mulyono [9] explained that the competencies and characteristics of individuals as employees appear in the form of knowledge, skills and behaviors, meanwhile an individual employee with decent competence will perform tasks in a professional, effective and efficient manner. Employees with good understanding (knowledge), attitudes, and skills are considered capable of controlling behavior, with a good mindset supported by a high understanding, so various problems related to obstacles in productivity and performance can be solved as effective and efficient as possible. 


\section{H2: Employee competence has a significant effect on Individual Performance}

Work environment and individual performance. Dharmanegara et al [20] explained that the work environment has an influence on the performance and action of employees in an organization. A positive work environment has an impact on improving employee performance. The condition of the work environment with a systematic system of work standards supported by work tool facilities is felt by employees to able to provide several impacts, one of which is an increasing productivity. Jayaweera's research [13] explains that the work environment can have an impact and influence on employee performance. The work environment is considered to have an impact on individual performance as an employee (individual performance). The conditions of comfort and good work environments therefore support the improvement of competencies and employee productivity.

\section{H3: Work Environment has a significant effect on Individual Performance}

\section{Method}

This research use a quantitative method, with a causality approach. Causality approach is a research approach to see the effect of one variable with another variable. Quantitative methods use a population research as well as specific samples for a statistical data analysis. This data analysis is intended to answer the problem formulation and test the truth of the hypothesis [22]. This study shows a causal relationship between exogenous variables and endogenous variables. This study examines the influence of the work environment and employee competencies on individual performance.

The population in this study are all 1750 employees at SMEs Keripik Tempe Malang. The sample is a small part of the number and characteristics that can represent the population [22]. The respondents to be used in this study are 100 employees. The sampling technique is purposive sampling. The respondents of this research are based on the criteria of employees who have been working at Sanan Tempe Chips Malang over one year.

This research uses a Partial Least Square (PLS) analysis. PLS is one of the variant-based SEM statistical methods that is designed to solve specific data problems, such as small sample sizes, missing data, and multicollinearity.

\section{Result And Discussion}

A construct indicator is to meet the convergent validity if it has a loading value of greater than 0.70 , which is used to measure latent variables. The results of convergent validity testing on work environment variables, HR competencies and individual performance show the values of greater than 0.70 , so the indicators can be declared valid as a measure of its latent variable.

The discriminant validity of each variable in measuring the items is indicated by cross loadings. Each indicator has a cross loading (of the dimensions or variables measured) greater than the value of the cross loading with other dimensions or variables, so all indicators fulfill the discriminant validity requirement.

The measurement test results are said to be reliable if they have Cronbach's alpha coefficient greater than 0.6. The test results show that the value of internal consistency reliability, for the alpha coefficient of each variable is declared reliable because they are 
greater than 0.6. Thus, the measurement items for each variable are declared reliable and can be used for this research.

Average Variance Extracted (AVE) is one of the validity test conditions based on the extracted average value of each variable. The results show that the values of AVE are greater than 0.5 , so it has fulfilled the convergent validity evaluation.

The result of $\mathrm{R}$ square is 0.830 or $83.0 \%$. This shows the variable diversity of work environment and competency can affect individual performance by $83.0 \%$. The remaining $17.0 \%$ is influenced by other variables outside the study. The results of the $\mathrm{R}$ square employee competence of 0.772 or $77.2 \%$ where the work environment can affect employee competence of $77.2 \%$. The remaining $22.8 \%$ is contributed by other variables not discussed.

Table 1. Hypothesis test result

\begin{tabular}{lcccc}
\hline \multicolumn{1}{c}{ Hypothesis } & $\begin{array}{c}\text { Original } \\
\text { sample }\end{array}$ & Sample & $\begin{array}{c}\text { Standard } \\
\text { Deviation }\end{array}$ & $\begin{array}{c}\text { T- } \\
\text { statistics }\end{array}$ \\
\hline Employee Competency $\rightarrow$ Individual Performance & 0.482 & 0.483 & 0.085 & 5.678 \\
Work Environment $\rightarrow$ Individual Performance & 0.458 & 0.458 & 0.087 & 5.268 \\
Work Environment $\rightarrow$ Employee Competency & 0.879 & 0.879 & 0.022 & 40.774 \\
\hline
\end{tabular}

Effect of work environment on employee competencies

The results of the tests listed in the above table can be seen that the T-statistic value of work environment on employee competencies is 40,774. The test results show that the Tstatistic value is greater than 1.96. This can be interpreted that the work environment has a significant influence on employee competencies.

Effect of Employee Competency on individual performance

The results of the tests listed in the above table can be seen that the T-statistic value of employee competencies on individual performance is 5.678. The test results show that the Tstatistic value is greater than 1.96 . This can be interpreted that employee competencies have a significant effect on individual performance.

Effect of work environment on individual performance

In the test results, it can be seen that the T-statistic value of work environment on individual performance is 5.268. The test results show that the T-statistic value is greater than 1.96. This can be interpreted that work environment has a significant influence on individual performance.

Table 2. Direct and Indirect Effect

\begin{tabular}{lccc}
\multicolumn{4}{c}{ Table 2. Direct and Indirect Effect } \\
\multicolumn{1}{c}{ Variable } & Direct & $\begin{array}{c}\text { Effect } \\
\text { Indirect }\end{array}$ & Total \\
\hline Employee Competency $\rightarrow$ Individual Performance & 0.482 & - & 0.482 \\
Work Environment $\rightarrow$ Individual Performance & 0.882 & - & 0.882 \\
Work Environment $\rightarrow$ Employee Competency & 0.879 & - & 0.879 \\
Work Environment $\rightarrow$ Individual Performance & 0.424 & $0.424 * 0.482$ & 0.204 \\
\hline
\end{tabular}

The results show that the work environment has a significant and positive effect on employee competencies. The business activities in SMEs need a conducive working environment to create comfortable ambience in working area. Oswald [18] explained that work environment influences employee competence. Employees, who like their work environment, contribute to the confidence and are encouraged to work optimally. 
The results indicate that employee competencies have a significant effect on individual performance. The competence of employees shows the ability to carry out roles and tasks, the ability to integrate knowledge, skills, attitudes, and personal values, and the ability to build knowledge and skills based on experience and learning of different reasons and goals. A study by Amiroso and Mulyanto [9] shows that employees competency appears in the form of knowledge, skills and behavior. Individuals who are competent will be able to carry out the tasks professionally, effectively and efficiently.

The results also show that the work environment has a direct and significant positive effect on individual performance. Work environment associated with a good work system, the attitude of cooperation among employees, the treatment of SME owners towards employees by providing assistance through learning can improve the ability of these employees. Quality work environments will improve employee performance [14]. Working environment conditions can encourage employees to work well, precisely and optimally. Dharmanegara et al [16] explain that the work environment has an influence on employee performance in an organization. Jayaweera [13] also explains that work environment influences individual performance as an employee. Work environment is considered to be able to provide impacts on improving individual performance as an employee. Good facilities and workplace conditions encourage employees to be able to work well.

\section{Conclusion}

The results show that the work environment has a significant effect on employee competency. Employee competency has a significant effect on individual performance. Furthermore, this study also shows the results that work environment has a significant effect on individual performance.

SME owners should pay attention to the work environment in terms of cleanliness and the completeness of the production equipments. Competencies of the worker should be improved by providing understanding on work assignments. Work environment variable, related to the indicator relationship with colleagues on the item statement of relationships between coworkers, gets the lowest value so the owners must always pay attention to the psychological conditions associated with relationships among employees. Business owners can create intimacy among employees so they are able to work together. For further research, it can add other variables that may affect individual performance, such as work motivation, job satisfaction, and employee involvement.

\section{References}

[1] Abuzah, F.: Data Statistik dan Hasil Survei Ekonomi Kreatif 2016. Badan Ekonomi Kreatif dan Badan Pusat Statistik (2019)

[2] Roswadi, M. L. N.: Industrikreatif dalam menghadapi pasar bebas asean tahun 2015. Jurnal Wawasan Hukum, Vol. 30, No. 1 (2015)

[3] Yusadi, R., Waluyo, B. S., Setyono, D. A.: Rencana aksi pengembangan industri kreatif kuliner berbasis media online di kota malang. Jurnal Tata Kota dan Daerah, Vol. 10, No. 2 (2018)

[4] Ferdinand.: Strategi Pengembangan Klaster Usaha Mikro Kecil dan Menengah Keripik Tempe di Sanan Malang. Manajemen (JAM), Vol. 14, No. 1 (2014) 
[5] June, Sethela, and Mahmood, Rosli.: The Relationship between Role Ambiguity, Competency and Person-Job Fit With the Job Performance of Employees in the Service Sector SMEs in Malaysia . Business Management Dynamics, Vol. 1, No. 2, August, pp.79-98 (2011)

[6] Muhammad, T.: Hubungan tingkat modal sosial terhadap tingkat pen $\neg$ da $\neg$ pa $\neg$ tan pelaku UKM (Studi pada sentra industri keripik tempe Sanan Malang). Jurnal FISIP Universitas Brawijaya Malang, Vol. 2, pp. 1-9 (2013)

[7] Haslberger, C., and Thomas.: Managing performance abroad a new model for understanding expatriate ajustment. Routledge Taylor and Francis Group, New York (2014)

[8] Pawirosumarto, Purwanto, and Rachmad.: The effect of work environment, leadership style and organizational culture towards job satisfaction and its implication towards employee performance in Parador Hotels and Resorts, Indonesia. International Journal of Law and Management, Vol. 7, No. 1, pp. 1-16 (2017)

[9] Amiroso, J., and Mulyanto.: Influence of discipline, working environment, culture of organization and competence on workers' performance through motivation, job satisfaction (Study in regional development planning board of Sukoharjo Regency). European Journal of Business and Management, Vol. 7, No. 36, pp. 86-95 (2015)

[10] Yossa, S., and Zunaidah. : Analisis Pengaruh Kemampuan Karyawan, Pembagian Tugas, Dan Motivasi Terhadap Kinerja Karyawan Pada PT. Pelabuhan Indonesia II (Persero) Cabang Palembang. Jurnal Manajemen dan Bisnis Sriwijaya, Vol.11 No.4 (2013)

[11] Le, D., T. and Pham, C. : Lecturer's Working Environment and Teaching Competence in Selected Agricultural Colleges in Vietnam. International Journal of Financial Research Vol. 7, No. 5 (2016)

[12] Hussein, F.: Kepuasan kerja dan kinerja pegawai, budaya organisasi, perilaku pemimpin dan efikasi diri. Elmatera, Yogyakarta (2017)

[13] Jayaweera, T.: Impact of work environmental factors on Job Performance, Mediating Role of Work Motivation: A Study of Hotel Sector in England. International Journal of Business and Management,Vol. 10, No. 3, pp. 271-278 (2015)

[14] Samani, S.A., Razid, R.Z.A, and Sofian.: Perceived level of personal control over the work environment and employee satisfaction and work performance. Performance Improvement, Vol. 54, No. 9 (2015)

[15] Yusuf, N., and Metiboba, S.: Work environment and job attitude among employees in a Nigerian work organization. Journal of Sustainable Society, Vol. 1, No. 2, pp. 36-43 (2012)

[16] Dharmanegara, I. B. A., Sitiari, N. W., Wirayudha, I D. G. N.: Job competency and work environment: The effect on job satisfaction and job performance among SMEs worker. Journal of Business and Management, Vol. 18, No. 1, pp. 19-26 (2016)

[17] Nikolajevaite, M., and Sabaityte, E.: Relationship Between Employees' Competencies and Job Satisfaction: British and Lithuanian Employees. Psychology Research, Vol. 6, No. 11, pp. 684$692(2016)$

[18] Oswald, A.: The effect of working environment on workers performance: The case of reproductive and child health care providers in Tarime District. Master thesis dissertation, Muhimbili University of Health and Allied Sciences (2012)

[19] Antwi, J. O., and Owusu, A.: Employee's competency and organizational performance in the pharmaceutical industry an empirical study of pharmaceutical firms in Ghana. International Journal of Economics, Commerce and Management United Kingdom, Vol. 3, No. 3, March (2015)

[20] Yani, A., and Indrawati, A.: Pengaruh lingkungan kerja dan motivasi kerja terhadap kompetensi guru bersertifikasi di SMK Negeri 1 Pasuruan. Jurnal Pendidikan Bisnis dan Manajemen, Vol. 2, No. 1, pp. 58-74 (2016)

[21] Chouhan, V. S., and Srivastava, S.: Understanding Competencies and Competency Modeling A Literature Survey IOSR. Journal of Business and Management, Issue 1, pp. 14-22 (2014)

[22] Sugiyono.: Metode penelitian kuantitatif, kualitatif dan R\&D. CV Alfabeta, Bandung (2016) 